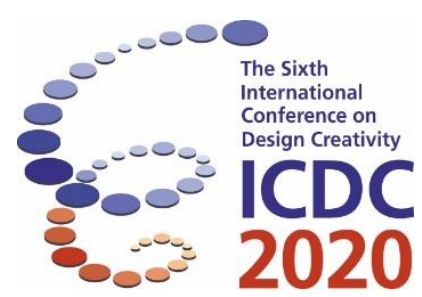

\title{
The effects of customers' cultural values on their perceptions of lodging service quality: A comparative analysis of customers at traditional Japanese inns
}

\author{
Nguyen PB Chau
}

School of Business Administration, Hitotsubashi University, Tokyo, Japan

\begin{abstract}
Growth in international travel has led to the need to be aware of cultural elements in designing services. This paper examines how consumers' culture influences their perceptions of lodging service quality with strong cultural characteristics, by comparing the evaluation of Asian and Western guests at Japanese-style inns (ryokan). Results show differences in their perceptions, with Western guests evaluating the service more preferably than Asian customers. The study suggests lodging facilities to consider the culture of their guests when designing their service environment.
\end{abstract}

Keywords: tourism, hospitality, lodging industry, culture, service quality

\section{Background and research purpose}

According to the World Tourism Organization (hereafter UNWTO), tourism accounts for $29 \%$ of global services export (UNWTO, 2019). The growth in tourism is also evident from the number of international tourist arrivals, which exceeded 1.4 billion in 2018 (UNWTO, 2019).

Traveling to other countries consists of unavoidable encounters with cultures that are different from our own. Such differences can affect the outcome of services. Employees and customers from different cultures may misunderstand each other's expected role (Sharma, Tam, \& Kim, 2012), leading to a lack of inter-role congruence (Solomon, Suprenant, Czepiel, \& Gutman, 1985) and failed service outcomes. Additionally, the service environment can also affect service quality. Servicescape, a term coined by Bitner (1992), has been found to influence consumers' perceptions (e.g. Kim \& Moon, 2009; Lin, 2016). Applying these findings to the tourism industry, it is expected that the environment of tourism services, especially those with strong cultural elements, plays a role in perceived service quality. Understanding how consumers with different cultural values evaluate such services will help managers take advantage of cultural elements in designing service environment. This paper, focusing on lodging as an area of tourism, aims to explore the following question: Do customers with different cultural values have different perceptions of service quality in the lodging service setting?

\section{Definition of Japanese style inns (ryokan)}

Chosen for this study is Japan, a country which is seeing considerable growth in tourism. The number of international tourist arrival to Japan exceeded 31 million in 2018, the highest since the tracking of the data began in 1964 (Japan National Tourism Organization, 2019). The country has also set the target of attracting 40 million international visitors by 2020 (Japan Tourism Agency, 2019). 
Since this paper will compare the perceptions of consumers at Japanese-style inns, it is useful to first clarify the definition of this accommodation type. 40

Japan's Hotel Business Act defines the term "hotel business" as "the business of operating an inn or hotel, the business of operating a common lodging house, or the business of operating a boarding house" (Japanese Law Translation, n.d.). Here, "the business of operating an inn or hotel" refers to "running a facility, receiving lodging fees, and allowing people to lodge there" (Japanese Law Translation, n.d.). Japan's Hotel Business Act divides the hotel business into four major categories: hotel, inn (ryokan), common lodging house, and boarding house. In the context of this Act, inns (ryokan) are defined as having "Japanese-style" facilities and equipment (Japanese Law Translation, n.d.). Japanese-style inns are typically characterized by tatami grass mats that require guests to remove their shoes at the entrance, futon mattress for sleeping, public baths (in many cases onsen, or hot spring), and Japanese cuisine (Ohe \& Peypoch, 2016). At Japanese-style inns, guests usually take a bath, dress in traditional Japanese clothing called yukata, and enjoy dinner consisting of several small dishes. Staff is usually women wearing kimono, who not only explain how to use the facilities but also prepare dinner and spread futon for guests to sleep on (Guichard-Anguis, 2008).

Staying at ryokans is one of the activities enjoyed by international tourists in Japan. A survey by the Japanese Tourism Agency (2019) revealed that 70\% of international tourists in Japan said they wanted to stay at a ryokan if possible. The top three reasons for choosing to stay in a ryokan are the Japanesecentric style of accommodation, bathing in a hot spring (onsen), and eating Japanese cuisine (Japan Ministry of Land, Infrastructure, Transport, and Tourism, 2014). This suggests the importance of Japanese aesthetics in guests' lodging experience.

\section{Literature review and hypothesis}

\subsection{Cultural values}

Cultural values are defined by Hofstede (1980) as "the collective programming of the mind" (p. 21). His theory initially identified four dimensions of culture: individualism versus collectivism, power distance, uncertainty avoidance, and masculinity versus femininity (Hofstede, 1980), which was later joined by long-term versus short-term orientation (Hofstede \& Bond, 1988) and indulgence versus restraint (Hofstede, Hofstede, \& Minkov, 2010). Such studies have demonstrated that people with different cultural values behave differently, or that cultural values "influence a human group's response to its environment (Hofstede, 1980, p. 21).

\subsection{Intercultural service encounters}

A service encounter is defined as a "period of time during which a consumer directly interacts with a service" (Shostack, 1985, p.243), and intercultural service encounters, in turn, are service encounters in which "the service provider and the customer involved belong to different cultures" (Stauss \& Mang, 1999, p.311).

According to role theory, both the customer and the service provider have implicit roles in a service encounter, and each side expects the other to act accordingly (Solomon et al., 1985; Broderick, 1999). Meeting these expectations, or fulfilling these roles, leads to the success of the service (Broderick, 1999). However, in intercultural service encounters, the differences in cultural values result in the misunderstanding of roles (Sharma et al., 2012), or the lack of inter-role congruence (Solomon et al. 1985), making it more difficult for the service to succeed.

\subsection{The impact of cultural values on service}

Previous literature has repeatedly used cultural values to explain the difference in customers' behavior in service encounters Zhang, Beatty, \& Walsh (2008) synthesized the impact of customers' cultural values on each of the three stages of service as categorized by Lovelock and Wirtz (2004): pre-purchase, service encounter and post-encounter. Customers hold certain expectations of the service before purchase. Then, they compare the actual performance with these expectations in the service encounter stage to form a judgment on whether or not the service was satisfactory. Finally, customers react 
accordingly in the post-encounter stage, such as complaining when the service experience was negative. The customers' cultural values form their expectation, perceptions, and reaction to service in each stage (Zhang et al., 2008).

For example, in the pre-purchase stage of airline services, it has been found that Americans expected more than Europeans (Sultan \& Simpson, 2000), Japanese expect more from the service in general than North American, West European and Chinese (Gilbert \& Wong, 2003), and European students expected more from employees' service than Malaysian counterparts (Lim \& Tkaczynski, 2017). In the service encounter stage, a study on dental service found Japanese to be stricter than Americans and Canadians in the perceptions of successful service performance, but more forgiving in case of unsuccessful one (Laroche, Ueltschy, Abe, Cleveland, \& Yannopoulos, 2004). Another study, also in the dental service setting, found that Chinese were more satisfied than Japanese and Koreans when service performance was high, but more dissatisfied when it was low (Ueltschy, Laroche, Zhang, Cho \& Yingwei, 2009). In the post-encounter stage, a large body of research has looked at service failure and also found a difference in customers' reaction based on their cultural values. In case of failed service in the restaurant setting, for instance, Americans are more likely to voice their opinion than South Koreans (Liu \& McClure, 2001) and Chinese (Fan, Mattila, \& Zhao, 2015).

\subsection{Measurement of lodging service quality}

Parasuraman, Zeithaml, and Berry (1988) developed a model called SERVQUAL to measure service quality. Their model is based on the notion that there are gaps between consumers' expectations of the service and their perceptions of the actual one (Parasuraman et al., 1988) and consists of two versions of items corresponding to the evaluation before and after experiencing the service. For example, an item on tangibles read "They should have up-to-date equipment" in reference to expectations, and "XYZ has up-to-date equipment" in reference to perceptions, with XYZ being the name of the service provider in question. The perceived quality is calculated as $\mathrm{Q}=\mathrm{P}-\mathrm{E}$, in which $\mathrm{Q}$ is the perceived quality, $\mathrm{P}$ is the perceptions of the particular service that consumers have experienced, and $\mathrm{E}$ is the expectation of the service in general. The purification process left five dimensions (tangibles, reliability, responsiveness, assurance, and empathy) consisting of a total of 22 items. Each item is rated on a 7-point Likert scale, with 1 being "Strongly disagree" and 7 being "Strongly agree."

In the development of the SERVQUAL scale, Parasuraman et al. (1988) noted that the measurement model was created with services in general in mind, and therefore adaptation is recommended for usage in specific service industries, including rewording and adjusting the number of items. In the lodging industry, SERVQUAL was adapted by Knutson, Stevens, Wullaert, Patton, and Yokoyama (1990) into LODGSERV. The model retained five dimensions of the but added some items to better reflect the lodging service context, resulting in a 26 -item measurement scale. Reliability and validity of the scale were tested (Knutson et al., 1990).

While there are other efforts to adapt the SERVQUAL into the lodging industry, such as LODGQUAL (Getty \& Thompson, 2003) or HOLSERV (Mei, Dean, \& White, 1999), the developers of the LODGSERV went further in the exploration to create a scale which can be used internationally. Patton, Stevens, and Knutson (1994) tested the LODGSERV model in Japanese, Mandarin Chinese, Cantonese Chinese, Australian English, and British English. The translation and back-translation process highlighted some terms that were difficult to understand in languages other than the original American English, and these terms were modified. After that, the scale was tested in Japan, Taiwan, Hong Kong, Australia, and the United Kingdom. The researchers concluded that the LODGSERV can be used outside of the United States.

\subsection{Hypothesis}

While the service quality evaluation of consumers of different cultures has been examined in the past, this study focuses on Japanese-style inns, which has distinctive cultural elements conveyed through servicescape in addition to Japanese service providers. In addition, the use of LODGSERV will help shed a light on the specific aspect of service quality with differences in evaluation.

Due to the length constraints, this paper will only address consumers' differences in perceptions (postexperience) of lodging services. As discussed, past studies have demonstrated dissimilarities in the 
evaluation of service quality by consumers of different cultures. This research, therefore, expects the same difference in the lodging industry and proposes the following hypothesis:

There is a significant difference among cultural groups in their perceptions of Japanese lodging service quality.

\section{Data collection}

Data were collected at two Japanese style inns, one in Western and one in Eastern Japan. These facilities are similar in terms of price and popularity, ranking in the top five of their respective area on TripAdvisor. Guests were given surveys at check-in and told to complete them by check-out to receive a discount of 2000 yen. The collection period lasted from March through November 2019.

In addition to the items based on the LODGSERV, participants were also asked to give information on their nationality and age. The surveys were translated into English, simplified Chinese, traditional Chinese, and Korean by bilinguals.

\section{Results}

\subsection{Demographic data}

A total of 161 responses were collected. The demographic characteristics of respondents are outlined in Table 1.

Table 1. Demographic data of sample $(\mathrm{n}=161)$

\begin{tabular}{|l|l|l|}
\hline & $\boldsymbol{N}$ & Percent \\
\hline Gender & & \\
Male & 56 & 34.78 \\
Female & 79 & 49.07 \\
N/A & 26 & 16.15 \\
\hline Age & & \\
29 years old and younger & 18 & 11.18 \\
30 to 49 years old & 75 & 46.58 \\
50 to 64 years old & 29 & 18.01 \\
65 years old and older & 12 & 7.45 \\
N/A & 27 & 16.77 \\
\hline Cultural group & & \\
Asian & 78 & 48.45 \\
Western & 60 & 37.27 \\
N/A & 23 & 14.29 \\
\hline
\end{tabular}

Asian sample consists of mainly Chinese guests, followed by those from Hong Kong, Taiwan, Thailand, Singapore, Malaysia, Korea, and Japan. Western guests were from the United States, Canada, France, Australia, the United Kingdom, Italy, Germany, Spain, Switzerland, Sweden, Ireland, Netherlands, Austria, Belgium, Denmark, and Portugal.

\subsection{Data analysis}

Independent samples t-tests were conducted to compare the post-experience evaluation between Asian and Western guests in each of the five LODGSERV categories as well as overall. Results show that there are significant differences in all dimensions and overall score. Although the scores are high in general, with all dimensions rated higher than 6 on the scale of 7, the rating by Asian guests are lower and with higher standard deviation (SD).

All dimensions were significant at the $\mathrm{p}<0.001$ level (Table 2). Therefore, the hypothesis is supported. 
Table 2. Independent Samples t-tests Comparing Perceptions of Japanese Lodging Service by Cultural Groups

\begin{tabular}{|c|c|c|c|c|c|c|c|c|}
\hline Dimensions & Cultural Groups & $\mathbf{n}$ & Mean & SD & t Stat & t Crit & df & $\mathbf{p}$ \\
\hline \multirow[t]{2}{*}{ Tangibles } & Asian & 78 & 6.45 & 0.54 & \multirow[t]{2}{*}{-3.49} & \multirow[t]{2}{*}{1.98} & \multirow[t]{2}{*}{136} & \multirow[t]{2}{*}{0.0006} \\
\hline & Western & 60 & 6.75 & 0.35 & & & & \\
\hline \multirow[t]{2}{*}{ Reliability } & Asian & 78 & 6.43 & 0.68 & \multirow[t]{2}{*}{-4.95} & \multirow[t]{2}{*}{1.98} & \multirow[t]{2}{*}{136} & \multirow[t]{2}{*}{$2.1464 \mathrm{E}-06$} \\
\hline & Western & 60 & 6.89 & 0.25 & & & & \\
\hline \multirow[t]{2}{*}{ Responsiveness } & Asian & 78 & 6.41 & 0.69 & \multirow[t]{2}{*}{-4.59} & \multirow[t]{2}{*}{1.98} & \multirow[t]{2}{*}{136} & \multirow[t]{2}{*}{$9.9488 \mathrm{E}-06$} \\
\hline & Western & 60 & 6.85 & 0.34 & & & & \\
\hline \multirow[t]{2}{*}{ Assurance } & Asian & 78 & 6.38 & 0.77 & \multirow[t]{2}{*}{-4.17} & \multirow[t]{2}{*}{1.98} & \multirow[t]{2}{*}{136} & \multirow[t]{2}{*}{$5.3958 \mathrm{E}-05$} \\
\hline & Western & 60 & 6.84 & 0.41 & & & & \\
\hline \multirow[t]{2}{*}{ Empathy } & Asian & 78 & 6.23 & 0.92 & \multirow[t]{2}{*}{-4.19} & \multirow[t]{2}{*}{1.98} & \multirow[t]{2}{*}{136} & \multirow[t]{2}{*}{$5.0183 \mathrm{E}-05$} \\
\hline & Western & 60 & 6.76 & 0.42 & & & & \\
\hline \multirow[t]{2}{*}{ Overall } & Asian & 78 & 6.38 & 0.64 & \multirow[t]{2}{*}{-4.83} & \multirow[t]{2}{*}{1.98} & \multirow[t]{2}{*}{136} & \multirow[t]{2}{*}{$3.6492 \mathrm{E}-06$} \\
\hline & Western & 60 & 6.81 & 0.31 & & & & \\
\hline
\end{tabular}

\section{Discussion}

This study looked at the effect of cultural characteristics on consumers' side on their perceptions, i.e. whether or not consumers of different cultures differ in their post-experience evaluation of lodging services, in the context of Japanese-style inns.

Customers evaluated the lodging services favorably, with all dimensions rated higher than 6 over the scale of 7. These scores reflect the status of these two accommodations as among the top in their respective area.

However, consumers of different cultural groups had significantly different perceptions of Japanese lodging services. Asian guests had lower evaluations of the service quality in comparison with Western customers across all dimensions and overall. Moreover, the higher SD in Asian guests' scores indicated that they varied more in the opinion of the lodging service. One explanation is Western guests are less familiar with Japanese culture, leading to stronger impressions of the ryokan experience. It is also possible that the information at these facilities is more available in English than Asian languages such as Chinese, which is an issue that needs to be addressed.

Nevertheless, the overall high scores suggest that managers should continue to take advantage of the distinctive ryokan design to enhance guests' evaluation. For example, facilities could inform guests of the experience at traditional Japanese-style inns through websites, brochures, and communication with staff. However, such measures should be carefully taken to preserve the ryokan atmosphere.

\section{Limitations and future research}

A larger sample size could provide more insights into the understanding of the effects of cultural elements on lodging service quality, such as allowing the comparison between more specific cultural groups. The findings could be generalized through the expansion of research to other countries and other price ranges.

In addition, to further investigate the effect of traditional Japanese design on guests' evaluation, comparisons could be made between Japanese and non-Japanese accommodations. Such research could reveal the advantages of cultural elements in designing lodging facilities.

\section{References}

Bitner, M. J. (1992). Servicescapes: The impact of physical surroundings on customers and employees. Journal of Marketing, 56(2), 57-71.

Broderick, A. (1999). Role theory and the management of service encounters. Service Industries Journal, 19(2), 117-131.

Fan, A., Mattila, A. S., \& Zhao, X. (2015). How does social distance impact customers' complaint intentions? A cross-cultural examination. International Journal of Hospitality Management, 47, 35-42. 
Getty, J. M., \& Thompson, K. N. (2003). Assessing customers' perceptions of lodging quality: LODGQUAL-a measure of quality for the lodging industry. International Journal of Contemporary Hospitality Management, 15(2), 94-104.

Gilbert, D., \& Wong, R. K. (2003). Passenger expectations and airline services: A Hong Kong based study. Tourism Management, 24(5), 519-532.

Guichard-Anguis, S. (2008). Japanese inns (ryokan) as producers of Japanese identity. In Guichard-Anguis, S., \& Moon, O. (Eds.), Japanese tourism and travel culture (pp. 76-101). Oxon, OX: Routledge.

Hofstede, G. (1980). Motivation, leadership, and organization: Do American theories apply abroad?. Organizational Dynamics, 9(1), 42-63. https://doi.org/10.1016/0090-2616(80)90013-3

Hofstede, G., \& Bond, M. H. (1988). The Confucius connection: From cultural roots to economic growth. Organizational Dynamics, 16(4), 5-21.

Hofstede, G., Hofstede, G. J., \& Minkov, M. (2010). Cultures and organizations: Software of the mind. (Third edition). London: McGraw-Hill.

Japan Ministry of Land, Infrastructure, Transport, and Tourism. (2014). Ryokan brand ni kansuru chosa kenkyu - Ryokan keieisha no gaikokujin ryokousha ukeire no jittai to gaikokujin shukuhakusha kara mita "ryokan" [A study on the ryokan brand: Current status on the acceptance of foreign tourists from the perspective of ryokan managers and "ryokan" from the perspective of foreign guests]. Japan Ministry of Land, Infrastructure, Transport, and Tourism. Retrieved from https://www.mlit.go.jp/pri/houkoku/gaiyou/pdf/kkk119.pdf

Japan National Tourism Organization. (2019). Nenbetsu kuni - chiiki goto no hounichi gaikyakusuu no suii [Change in international tourists to Japan through the years by countries/ regions]. Japan National Tourism Organization. Retrieved from https://statistics.jnto.go.jp/graph/\#graph--trends--by--country (December 21st, 2019)

Japan Tourism Agency (2019). “Taikengata kankou content shijo no gaikan”: Sekai no kotoshouhi to kaigairyokousha no ishiki jittai no chousakekka [An overview of contents experience tourism market: Study results on intangible consumption worldwide and thoughts and status of international tourists]. Japan Tourism Agency. Retrieved from https://www.mlit.go.jp/common/001279555.pdf (December 20th, 2019)

Japanese Law Translation. (n.d.). Hotel business act. Japanese Law Translation. Retrieved from http://www.japaneselawtranslation.go.jp/law/detail_main?re=02\&vm=04\&id=3272

Kim, W. G., \& Moon, Y. J. (2009). Customers' cognitive, emotional, and actionable response to the servicescape: A test of the moderating effect of the restaurant type. International journal of hospitality management, 28(1), 144156.

Lin, I. Y. (2016). Effects of visual servicescape aesthetics comprehension and appreciation on consumer experience. Journal of Services Marketing, 30(7), 692-712.

Knutson, B., Stevens, P., Wullaert, C., Patton, M., \& Yokoyama, F. (1990). LODGSERV: A service quality index for the lodging industry. Hospitality Research Journal, 14(2), 277-284.

Laroche, M., Ueltschy, L. C., Abe, S., Cleveland, M., \& Yannopoulos, P. P. (2004). Service quality perceptions and customer satisfaction: Evaluating the role of culture. Journal of International Marketing, 12(3), 58-85.

Lim, S. S., \& Tkaczynski, A. (2017). Origin and money matter: The airline service quality expectations of international students. Journal of Hospitality and Tourism Management, 31, 244-252.

Liu, R. R., \& McClure, P. (2001). Recognizing cross-cultural differences in consumer complaint behavior and intentions: An empirical examination. Journal of Consumer Marketing, 18(1), 54-75.

Lovelock, C., \& Wirtz, J. (2004). Services Marketing: People, Technology, Strategy. New Jersey, NJ: Pearson Prentice Hall.

Mei, A. W. O., Dean, M., \& White, C. J. (1999). Analysing service quality in the hospitality industry. Managing Service Quality: An International Journal, 9(2), 136-143.

Ohe, Y., \& Peypoch, N. (2016). Efficiency analysis of Japanese Ryokans: A window DEA approach. Tourism Economics, 22(6), 1261-1273.

Parasuraman, A., Zeithaml, V. A., \& Berry, L. L. (1988). Servqual: A multiple-item scale for measuring consumer perc. Journal of Retailing, 64(1), 12-40.

Patton, M., Stevens, P., \& Knutson, B. J. (1994). Internationalizing LODGSERV as a measurement tool: a pilot study. Journal of Hospitality \& Leisure Marketing, 2(2), 39-55.

Sharma, P., Tam, J. L., \& Kim, N. (2012). Intercultural service encounters (ICSE): An extended framework and empirical validation. Journal of Services Marketing, 26(7), 521-534.

Shostack, G. L. (1985). Planning the Service Encounter. In Czepiel, J. A., Solomon, M. R., \& Suprenant, C. F. (Eds.), The service encounter: Managing employeel customer interaction in service businesses (pp. 243-254). Lexington, MA: Lexington Books. 
Solomon, M. R., Surprenant, C., Czepiel, J. A., \& Gutman, E. G. (1985). A role theory perspective on dyadic interactions: The service encounter. Journal of Marketing, 49(1), 99-111.

Stauss, B., \& Mang, P. (1999). "Culture shocks" in inter-cultural service encounters?. Journal of Services Marketing, 13(4/5), 329-346.

Sultan, F., \& Simpson, M. C. (2000). International service variants: Airline passenger expectations and perceptions of service quality. Journal of Services Marketing, 13(3), 188-216.

Ueltschy, L. C., Laroche, M., Zhang, M., Cho, H., \& Yingwei, R. (2009). Is there really an Asian connection? Professional service quality perceptions and customer satisfaction. Journal of Business Research, 62(10), 972979.

United Nations World Tourism Organization. (2019). International Tourism Highlights, 2019 Edition. United Nations World Tourism Organization. Retrieved from https://www.eunwto.org/doi/pdf/10.18111/9789284421152

Zhang, J., Beatty, S. E., \& Walsh, G. (2008). Review and future directions of cross-cultural consumer services research. Journal of Business Research, 61(3), 211-224.

\section{Appendix}

\begin{tabular}{|c|c|}
\hline Dimensions & Items (This hotel...) \\
\hline \multirow[t]{6}{*}{ Tangibles } & 1) ... have personnel who are clean, neat and appropriately dressed. \\
\hline & 2) ... serve food and beverages that are consistently high in quality. \\
\hline & 3) ... give you a room which is visually attractive. \\
\hline & 4) ... have décor consistent in keeping with its image and price range. \\
\hline & 5) ... have buildings, lobbies, and public areas which are visually attractive to you. \\
\hline & 6) ... have up-to-date equipment. \\
\hline \multirow[t]{4}{*}{ Reliability } & 7) ... have utilities and equipment that work well. \\
\hline & 8) ... are dependable, consistent, and able to be counted on. \\
\hline & 9) ... quickly correct anything that is wrong. \\
\hline & 10) ... provide promised or advertised services on time. \\
\hline \multirow[t]{3}{*}{ Responsiveness } & 11) ... provide prompt and quick service. \\
\hline & 12) ... have personnel shift to help where lines occur. \\
\hline & 13) ... have staff that gives extra effort to handle your special requests. \\
\hline \multirow[t]{5}{*}{ Assurance } & 14) ... have personnel who seem well-trained, competent and experienced. \\
\hline & 15) ... make you feel comfortable and confident in your dealing with them. \\
\hline & 16) ... seem to give employees support so they can do their jobs well. \\
\hline & $\begin{array}{c}\text { 17) ... have personnel who are both able and willing to give you information about hotel } \\
\text { and outside services. }\end{array}$ \\
\hline & $\begin{array}{l}\text { 18) ... have knowledgeable phone reservationists who answer your questions } \\
\text { completely. }\end{array}$ \\
\hline \multirow[t]{8}{*}{ Empathy } & 19) ... make you feel like a special and valued guest. \\
\hline & 20) ... have employees who are sympathetic and reassuring if something is wrong. \\
\hline & 21) ... eliminate unnecessary bureaucracy to contact a hotel manager or supervisor. \\
\hline & 22) ... have operating hours convenient to all their customers. \\
\hline & $\begin{array}{l}\text { 23) ... have employees who are sensitive to your individual needs and wants rather than } \\
\text { always going by the book. }\end{array}$ \\
\hline & 24) ... anticipate your individual needs and wants. \\
\hline & $\begin{array}{l}\text { 25) ... provide complimentary services like courtesy shuttles, morning coffee and } \\
\text { morning newspaper. }\end{array}$ \\
\hline & $\begin{array}{c}\text { 26) ... have restaurant and room service menus that include healthful and/or special diet } \\
\text { options. }\end{array}$ \\
\hline
\end{tabular}

